\title{
Analysis of the application of selected physico- chemical methods in eliminating odor nuisance of municipal facilities
}

\author{
Urszula Miller ${ }^{1, *}$, Agnieszka Grzelka ${ }^{1}$, Elżbieta Romanik $^{1}$ and Magdalena Kuriata ${ }^{2}$ \\ ${ }^{1}$ Unit of Engineering and Protection of Atmosphere, Faculty of Environmental Engineering, Wroclaw \\ University of Science and Technology, Pl. Grunwaldzki 9, 50- 377 Wroclaw \\ ${ }^{2}$ Faculty of Environmental Engineering, Wroclaw University of Science and Technology, Pl. \\ Grunwaldzki 9, 50- 377 Wroclaw
}

\begin{abstract}
Operation of municipal management facilities is inseparable from the problem of malodorous compounds emissions to the atmospheric air. In that case odor nuisance is related to the chemical composition of waste, sewage and sludge as well as to the activity of microorganisms whose products of life processes can be those odorous compounds. Significant reduction of odorant emission from many sources can be achieved by optimizing parameters and conditions of processes. However, it is not always possible to limit the formation of odorants. In such cases it is best to use appropriate deodorizing methods. The choice of the appropriate method is based on in terms of physical parameters, emission intensity of polluted gases and their composition, if it is possible to determine. Among the solutions used in municipal economy, there can be distinguished physico-chemical methods such as sorption and oxidation. In cases where the source of the emission is not encapsulated, odor masking techniques are used, which consists of spraying preparations that neutralize unpleasant odors. The paper presents the characteristics of selected methods of eliminating odor nuisance and evaluation of their applicability in municipal management facilities.
\end{abstract}

\section{Introduction}

In order to reduce the emission of odor nuisance, odorants formation can be prevented by the choice of technology and the proper conduct of the processes, or by using different methods of deodorizing the waste gases. Among the most commonly used methods, a group of physico-chemical methods can be distinguished, including sorption, oxidation and neutralization methods. The world-wide efforts aim to refine the methods and increase their potential to reduce odor nuisance of many objects. The variety of gases emitted and the variability of pollutant concentrations contained therein influences the efficiency of the methods and determines the choice of the particular case. Selection of methods and design of deodorization equipment should be subordinated to the following quantities: stream and

* Corresponding author: urszula.miller@pwr.edu.pl 
composition of the contaminated gas, process efficiency and the amount of investment and operating costs. Choosing an effective method is often based on many years of engineering experience. The paper presents advantages and disadvantages of selected physico-chemical methods of deodorization together with the assessment of their applicability in municipal facilities.

\section{Deodorization methods}

\subsection{Sorption methods}

Sorption techniques (absorption and adsorption) for the reduction of odor nuisance are included in physical deodorization methods.

Absorption is one of the more effective methods, especially in the case of large gas streams and concentrations of the dominant odorants (e.g. $\mathrm{H}_{2} \mathrm{~S}, \mathrm{NH}_{3}$ ). Absorption is usually combined with a chemical reaction that results in the separation of impurities from the gas phase to the liquid phase. The nature of the gas flow through the column (absorber) is determined by the designer at the selection stage and is closely related to the nature of the removed impurities. The absorption rate is influenced by the rate of penetration of the mass, which depends on the solubility of the gaseous pollutants. The disadvantage of this technique is the inconvenient wastewater with an aggressive nature, which also needs to be processed.[1, 2]

Sorption methods are highly effective against organic odorants, including volatile organic compounds. They can also be used to limit emissions of inorganic compounds such as ammonia [2]. The choice of method of contacting the gas with the liquid depends on the physicochemical properties of the absorption system

Most often during the deodorization process, air from the composting plant contaminated with fragrances is subjected to an absorption process in a crossflow scrubber. The air flows horizontally through a series of columns in which it contacts with the liquid containing neutralizing compounds. The system is characterized by a low pressure drops of spraying liquid and low operating costs. This solution allows multi-stage absorption of impurities without the need for additional connections between individual devices. The absorption liquid is sprayed on the construction elements of the filling, thus increasing the contact surface. By application of such construction, the contaminants of different physicochemical structures can be removed at the same time. For example, one column removes ammonia (NH3) by spraying the contaminated air with sulfuric acid, and in further stages, (columns II and III) hydrogen sulphide (H2S) or mercaptans can be removed by distillation of hydrogen peroxide $\left(\mathrm{H}_{2} \mathrm{O}_{2}\right)$ [1]. The choice and use of chemicals are dependent on the concentration, the type of contaminants and the required process efficiency. The treated gases coming out of the scrubber are then sent to the biofilter.

Examples of two-stage systems for removing odors are [1]:

- Oława composting plant with a counterflow scrubber GSW-230 with a flow rate of $18,000 \mathrm{~m}^{3} / \mathrm{h}$ - and biofilter with total area of $154 \mathrm{~m}^{2}$

- Tychy - two counterflow scrubbers GSW-410-P with a flow rate of $2 \times 65,000 \mathrm{~m}^{3} / \mathrm{h}$,

- Ostrołęka - two scrubbers with a flow of $2 \times 20000 \mathrm{~m}^{3} / \mathrm{h}$ and a three-chamber biofilter with a total area of $400 \mathrm{~m}^{2}$,

- Stalowa Wola - a counterflow scrubber GSW-300-P with a flow rate of the 48,000 $\mathrm{m}^{3} / \mathrm{h}$ and a $2 \times 192 \mathrm{~m}^{2}$ biofilter.

Adsorption on activated carbon is based on the accumulation of molecules on the surface of the adsorbent due to the presence of intermolecular forces or the formation of chemical 
bonds. The speed of this process is determined by the diffusion rate of the adsorbate to the surface. The adsorption efficiency is influenced by a number of factors, both surface and activated coal properties (pore distribution, particle size) and solution properties $(\mathrm{pH}$, temperature).

The efficiency of the adsorption process increases with [3]:

- molecular weight drop of the removed impurities,

- temperature drop (with the temperature rise, the process is reversed - desorption),

- solubility drop of pollutants,

- increase contact time in the bed.

A comparison of the chemical absorption and adsorption on activated carbon methods is presented in table 1 .

Table 1. Comparison of deodorizing methods $[2,4,5,6]$

\begin{tabular}{|c|c|c|c|}
\hline Method & Advantages & Disadvantages & Field of application \\
\hline $\begin{array}{l}\text { Chemical } \\
\text { absorption }\end{array}$ & $\begin{array}{l}\text { - Flexibility for variable } \\
\text { inlet conditions } \\
\text { - Process stability } \\
\text { - High efficiency at high } \\
\text { concentrations of } \\
\text { pollutants } \\
\text { - No adaptive time } \\
\text { - Full automation of the } \\
\text { process } \\
\text { - Low pressure drop of } \\
\text { sprayed liquid } \\
\text { - Simple construction }\end{array}$ & $\begin{array}{l}\text { - High investment costs } \\
\text { - Consumption of } \\
\text { chemicals } \\
\text { - Operating costs } \\
\text { - The presence of } \\
\text { disruptive sewage, } \\
\text { - Need for costly, } \\
\text { corrosion-resistant } \\
\text { materials } \\
\text { - The presence of } \\
\text { aggressive and } \\
\text { dangerous reagents }\end{array}$ & $\begin{array}{l}\text { - fat industry } \\
\text { - tannery } \\
\text { - tobacco fermentation } \\
\text { - production of } \\
\text { pharmaceuticals } \\
\text { - production of fatty acids } \\
\text { - waste water treatment } \\
\text { - production of dyes, } \\
\text { amines, phenolic resins, } \\
\text { methyl methacrylate }\end{array}$ \\
\hline $\begin{array}{l}\text { Adsorption } \\
\text { on } \\
\text { activated } \\
\text { carbon }\end{array}$ & $\begin{array}{l}\text { - Low investment costs } \\
\text { - Small surface } \\
\text { - High performance at the } \\
\text { beginning of the process }\end{array}$ & $\begin{array}{l}\text { - High operating costs } \\
\text { - Consumption and } \\
\text { regeneration of activated } \\
\text { carbon } \\
\text { - Narrow application } \\
\text { range } \\
\text { - No ammonia removal, } \\
\text { ammonia and odorant } \\
\text { removal } \\
\text { - High sensitivity to } \\
\text { changes in temperature } \\
\text { and humidity }\end{array}$ & $\begin{array}{l}\text { - sewage treatment plants } \\
\text { - fat industry } \\
\text { - food industry } \\
\text { - production of paints and } \\
\text { varnishes } \\
\text { - production of pesticides } \\
\text { - thought the paper }\end{array}$ \\
\hline
\end{tabular}

Most of the described deodorizing installations are characterized by a multistage process. In the first stage, acidic sorption solutions (removal of alkaline impurities such as ammonia) are used, and in subsequent steps - e.g. $\mathrm{NaOH}$ solutions and sodium hypochlorite (removal of sulfur compounds) are used. The danger of emissions of organic chlorine compounds is avoided by ozone usage as an oxidizing agent.

These methods are used primarily in the deodorization of gases from wastewater treatment processes as well as in waste management, either alone or as a stage of the purification system. It is common practice to use spray scrubbers in combination with biological methods to moisturize and cool gases, which then go to the biofilter (bed drying prevention) and also reduce the acidification of the bed.

\subsection{Oxidation methods}


Methods of oxidation of odorous pollutants include: thermal oxidation, catalytic oxidation, and plasma methods [7]. Thermal oxidation is a process of oxidation of combustible gases at a high temperature in the presence of oxygen. Depending on the type and amount of pollutants, the oxidation process is carried out directly in flame or thermally. The efficiency of the thermal combustion is high, almost 100\% [8]. During catalytic oxidation, the oxidation of gases takes place on the surface of the catalyst. This gives the same level of combustion at lower temperatures, and, therefore with lower fuel consumption [9]. The main parameters for designing of thermal or catalytic oxidation systems are: residence time, temperature and mixing. The average residence time for the oxidation of aroma compounds is from 0.25 to $0.6 \mathrm{~s}$ [10]. Non-thermal oxidation processes are: ozone, UV, non-thermal plasma. The non-thermal plasma technology uses strong alternating electrical currents or microwave radiation. So, produced plasma results in the decomposition of gaseous pollutants [11]. Comparison of oxidation methods is shown in Table 2 .

Table 2. Comparison of oxidation methods [5]

\begin{tabular}{|c|c|c|c|c|}
\hline Method & Parameters & Advantages & Disadvantages & $\begin{array}{c}\text { Field of } \\
\text { application }\end{array}$ \\
\hline $\begin{array}{l}\text { Thermal } \\
\text { oxidation }\end{array}$ & $\begin{array}{l}\text { - Temperature: } \\
923-1173 \mathrm{~K} \\
\text { - Concentration of } \\
\text { pollutants: high } \\
\text { - Continuous } \\
\text { measurement of } \\
\text { carbon dioxide, } \\
\text { oxygen, carbon } \\
\text { monoxide and } \\
\text { nitrogen oxides in } \\
\text { waste gases }\end{array}$ & $\begin{array}{l}\text { - Broad scope of } \\
\text { application } \\
\text { - Heat recovery }\end{array}$ & $\begin{array}{l}\text { - High fuel consumption } \\
\text { - Pre-treatment of gases } \\
\text { - humidity reduction, } \\
\text { dust removal, removal } \\
\text { of solid and liquid } \\
\text { particles } \\
\text { - soot formation }\end{array}$ & $\begin{array}{l}\text { - waste incineration } \\
\text { plants } \\
\text { - treatment of } \\
\text { animal waste } \\
\text { - coffee roasters } \\
\text { - paintshop } \\
\text { - production of } \\
\text { synthetic rubber } \\
\text { - refining of oil }\end{array}$ \\
\hline $\begin{array}{l}\text { Catalytic } \\
\text { oxidation }\end{array}$ & $\begin{array}{l}\text { - Temperature: } \\
623-673 \mathrm{~K} \\
\text { - The need to use a } \\
\text { catalyst } \\
\text { - Concentration of } \\
\text { pollutants: high }\end{array}$ & $\begin{array}{l}\text { - High } \\
\text { efficiency } \\
\text { - Heat recovery } \\
\text { - The gases may } \\
\text { be slightly dusty } \\
\text { or slightly damp } \\
\text { - For the } \\
\text { purification of } \\
\text { hot gases }\end{array}$ & $\begin{array}{l}\text { - Limited flow of } \\
\text { purified air } \\
\text { - Necessity to remove } \\
\text { solids } \\
\text { - Sensitive catalyst } \\
\text { - Formation of sulfur } \\
\text { dioxide and hydrogen } \\
\text { chloride } \\
\text { - The need for } \\
\text { additional purification; } \\
\text { - The need to ensure a } \\
\text { constant concentration } \\
\text { of pollution }\end{array}$ & $\begin{array}{l}\text { - treatment of } \\
\text { animal waste } \\
\text { - plastics } \\
\text { processing } \\
\text { - coffee roasters } \\
\text { - production of } \\
\text { synthetic rubber } \\
\text { - refining of oil } \\
\text { - paintshop }\end{array}$ \\
\hline $\begin{array}{l}\text { Non- } \\
\text { thermal } \\
\text { plasma }\end{array}$ & $\begin{array}{l}\text { - Reactive radicals } \\
\text { and ions react with } \\
\text { odorous compound } \\
\text { - Electric power } \\
\text { supply to the high } \\
\text { voltage; }\end{array}$ & $\begin{array}{l}\text { - For all gaseous } \\
\text { pollutants } \\
\text { - No waste }\end{array}$ & $\begin{array}{l}\text { - The formation of } \\
\text { excess ozone }\end{array}$ & $\begin{array}{l}\text { - sterilization and } \\
\text { disinfection } \\
\text { - paintshop } \\
\text { - combustion of } \\
\text { medical waste } \\
\text { processes } \\
\text { - chemical } \\
\text { processes } \\
\text { - food industry }\end{array}$ \\
\hline
\end{tabular}


Studies on the use of photocatalytic oxidation were carried out using ammonia as an odorant [12]. Typical catalyst reactivity was compared with catalyst activity with additional UV radiation. The results are shown in Table 3.

Table 3. Results of photocatalytic oxidation of ammonia [12]

\begin{tabular}{|c|c|c|c|}
\hline Catalyst composition & Efficiency & $\begin{array}{c}\text { Reaction } \\
\text { temperature without } \\
\text { UV }\end{array}$ & $\begin{array}{c}\text { Reaction } \\
\text { temperature with UV }\end{array}$ \\
\hline $5 \% \mathrm{Cu} / 5 \% \mathrm{TiO}_{2} / \mathrm{SiO}_{2}$ & $100 \%$ & $500{ }^{\circ} \mathrm{C}$ & $350{ }^{\circ} \mathrm{C}$ \\
\hline $5 \% \mathrm{Cu} / 10 \% \mathrm{TiO}_{2} / \mathrm{SiO}_{2}$ & $90 \%$ & $410{ }^{\circ} \mathrm{C}$ & $300{ }^{\circ} \mathrm{C}$ \\
\hline
\end{tabular}

In the study of the use of plasma techniques in the reduction of odors [13] reverse discharge reactor (I-7), electric barrier-discharge plasma with a grid electrode (W-1) and electric barrier-discharge plasma with a spiral electrode (IEL-4) were compared. The results obtained for the reactors are summarized in table 3 and showed that for the IEL-4 reactor with decreasing propane concentration the deodorant efficiency decreased. Better results were obtained for the Sz-1 reactors, but they were characterized by smaller gas flows and greater energy input.

Table 4. Results of research on the use of plasma techniques [13]

\begin{tabular}{|c|l|l|l|l|}
\hline Reactor & \multicolumn{1}{|c|}{ Pollutant } & \multicolumn{1}{|c|}{ Gas flow } & \multicolumn{1}{c|}{$\begin{array}{c}\text { Ionization } \\
\text { energy }\end{array}$} & \multicolumn{1}{|c|}{ Efficiency } \\
\hline \multirow{2}{*}{ I-7 } & $\begin{array}{l}\text { acetone } \\
\text { ethanol } \\
\text { toluene } \\
\text { xylene }\end{array}$ & $215 \mathrm{l} / \mathrm{h}$ & $600 \mathrm{~J} / 1$ & $>50 \%$ \\
\hline \multirow{2}{*}{ Sz-1 } & $\begin{array}{l}\text { cyclopentane } \\
\text { pentane } \\
\text { cyclohexane }\end{array}$ & $370 \mathrm{l} / \mathrm{h}$ & $10000 \mathrm{~J} / 1$ & $>50 \%$ \\
\cline { 2 - 5 } & propane & $46 \mathrm{l} / \mathrm{h}$ & $36000 \mathrm{~J} / 1$ & $90 \%$ \\
\hline IEL-4 & & $20 \mathrm{~J} / 1$ & $75 \%$ \\
\hline
\end{tabular}

For the IEL-4 reactor with decreasing propane concentration, the deodorant efficiency decreased. Better results were obtained for the Sz-1 reactors, but they were characterized by smaller gas flows and greater energy input.

In municipal economy oxidation methods are used when the concentration of pollutants is very high, eg the combustion of fermentation gas or the catalytic oxidation of gases from waste incineration. Plasma methods, which allow simultaneous disinfection and sterilization, are also of great potential.

Ozone has excellent oxidizing properties, but it is characterized by high toxicity. Therefore, the main limitation of the use of ozone in the gas phase in the deodorization of gases is due to the need to remove large quantities of unreacted ozone. Better results are obtained with the use of liquid phase ozonation, what results in higher costs [14]. This method is recommended when gases contain non-biodegradable pollutants and it is not possible to use biological methods [15]. The ozone performance (at $50 \mathrm{ppm}$ ozone concentration) is shown in Table 5.

Table 5. Results of photocatalytic oxidation of ammonia [15]

\begin{tabular}{|c|c|}
\hline Compound & Efficiency, \% \\
\hline trichloroethene & 35,5 \\
\hline
\end{tabular}




\begin{tabular}{|c|c|}
\hline tetrachloroethene & 94,8 \\
\hline benzene & 99,2 \\
\hline cyclohexane & 97,5 \\
\hline toluene & 99,1 \\
\hline chlorobenzene & 99,8 \\
\hline 1,2 -dichlorobenzene & 99,0 \\
\hline $1,3,5$-trichlorobenzene & 99,9 \\
\hline
\end{tabular}

\subsection{Neutralization methods}

In neutralization methods (modification of the aroma), there can be distinguished such methods as fogging, wet barrier and odor masking. Each of them relies on the introduction of volatile compounds, that changes the nature of the odor or the perceived olfactory sensation $[5,16]$. Fogging is a method consisting of spraying of appropriate chemicals in the gas stream. It is used for surface sources, especially when it is not possible to capture gases in organized emission [17]. The technology has been created to reduce odor nuisance, above all, in open space (diffuse emission) for example: sludge fields, landfills of wastes, and space closed (organized emission) for example transshipment halls and waste sorting plants.

Table 6 summarizes the main advantages and disadvantages of odor neutralizing methods and examples of their applicability.

Table 6. Advantages, disadvantages and Field of application of odor masking [5]

\begin{tabular}{|c|c|c|}
\hline Advantages & Disadvantages & Field of application \\
\hline $\begin{array}{l}\text { - moderate costs } \\
\text { - ease of use and mobility } \\
\text { - small storage area }\end{array}$ & $\begin{array}{l}\text { - sensitivity to changes in an } \\
\text { odor concentration } \\
\text { - possibility of secondary odor } \\
\text { formation } \\
\text { - dependence on the distance } \\
\text { from the odor source }\end{array}$ & $\begin{array}{l}\text { - modernization of the } \\
\text { installation - as a temporary } \\
\text { solution } \\
\text { - for a short period of time / } \\
\text { seasonally } \\
\text { - when it is possible to apply } \\
\text { directly on the odor source }\end{array}$ \\
\hline
\end{tabular}

Table 7 shows the sample results of laboratory tests on the masking of unpleasant odors using essential oils. In the presented studies [18, 19, 20], pine, lemon, and orange flavoring oils were used in two different concentrations of sewage sludge from municipal sewage treatment plants. The results indicate that, as the dose of the oil increases, the odor retention time increases. Relatively the longest retention times were found in pine oil.

Table 7. Results of research on the use of essential oils form odor masking [18, 19, 20]

\begin{tabular}{|c|c|c|}
\hline \multirow{2}{*}{ Type of essential oil } & \multicolumn{2}{|c|}{ Odor retention time for essential oil dose [min] } \\
\cline { 2 - 3 } & $0,06 \mathrm{~cm}^{3} / 100 \mathrm{~cm}^{3}$ sludge & $0,18 \mathrm{~cm}^{3} / 100 \mathrm{~cm}^{3}$ sludge \\
\hline pine & 14 & 30 \\
\hline lemon & 7 & 24 \\
\hline orange & 5 & 25 \\
\hline
\end{tabular}

Masking odors is not a deodorizing method. Sprayed fragrances cover the emitted odors, but they do not remove odorogenic compounds, and, by reacting with impurities, may cause 
secondary odor nuisances. Masking odors should therefore only be a temporary solution, eg during maintenance or failure of the gas purification system. A particular application may also be found in waste management in composting processes in closed pits when the odor emission is temporary (during throwing pits).

\section{Summary}

It is best to prevent odor emissions by preventing them from the formation. In the case of communal facilities it is not always possible, so the solution to the problem of odorant pollution is different methods of deodorization. The adsorption and absorption methods used for gases that are highly humid are commonly used, but the operating costs of these types of installations are relatively high. A very effective method is to combust contaminated gases, but for economic reasons, this technology is mostly used only for high temperature gases. There are also a number of indirect solutions (masking, fogging). However, they should only be used in the form of supplements to control non-toxic odorants which are characterized by low concentrations.

This work was supported by a statutory research No. 0401/0003/17

\section{References}

1. T. Pfliegensdörfe, M. Szołtys, Komunalny PLUS, 4, (2015)

2. J. Kwaśny, W. Balcerzak, Archives of Waste Management and Environmental Protection, vol. 16, 4, (2014)

3. M. Szołtys, Metody usuwania złowonnych zanieczyszczeń gazowych - porównanie technologii, http://tholander.pl/artykuly/metody-usuwania/ [available 10.11.2017]

4. I. Sówka, P. Zwoździak, A. Zwoździak, J. Zwoździak [in :]: Ekotoksykologia w ochronie środowiska. Polskie Zrzeszenie Inżynierów i Techników Sanitarnych. Oddział Dolnośląski, (2008)

5. Department of Air and Climate Protection, Code of anti-odor nuisance, Warsaw 2016

6. L. Wang, J. R. Taricska, Y. Hung, J. Eldridge, K. Hung Li, Air Pollut. Control Eng., 1, 2004

7. M. Słomińska, S. Król, J. Namieśnik, Crit Rev Env Sci Tec, 43, (2013)

8. M.I. Szynkowska, E. Wojciechowska, A. Węglińska, T. Paryjczak, Przem Chem, 88, 6 (2009)

9. G. Busca, C. Pistarino, J Loss Prevent Proc, 16 (2003)

10. D. Gabriel, X. Gamisans, R. Muñoz and J. Lafuente, [in:] J.M Lema; S. Suárez, Innovative wastewater treatment \& resource recovery technologies : impacts on energy, economy and environment. IWA Publishing, London, UK (2017)

11. M. Schlegelmilch, J. Streese, R. Stegmann, Waste Manage, 25, (2005)

12. M.I. Szynkowska, E. Leśniewska, E. Maćkiewicz, A. Węglińska, Z. Gorzka, J. Rogowski, J, Góralski, Ł. Kowalczyk, W. Maniukiewicz, A. Żarczyński, T. Paryjczak, [in:] M.I. Szynkowska, J. Zwoździak, Współczesna problematyka odorów, (Wyd. Naukowo-Techniczne, Warszawa 2010)

13. W. Mielcarek, R. Kacprzyk, J. Subocz, J. Rutkowski, G. Gryglewicz, S. Gryglewicz, K. Prociów, J. Warycha, T. Czapka, [in:] M.I. Szynkowska, J. Zwoździak, Współczesna problematyka odorów, (Wyd. Naukowo-Techniczne, Warszawa (2010) 
14. J. Waluś, P. Tatoj, T. Kaczyńska, M. Palica, K. Chmiel, Annual Set the Environment, (2001)

15. J. Ozonek [in:] M.I. Szynkowska, J. Zwoździak, Współczesna problematyka odorów. Wyd. Naukowo-Techniczne, Warszawa (2010)

16. Description of bioArcus technology, www.bioarcus.pl [available 15.11.2017]

17. I. Sówka, J. Zwoździak, M. Szklarczyk, A. Nych, M. Skrętowicz [in:] M.I. Szynkowska, J. Zwoździak, Współczesna problematyka odorów. Wyd. NaukowoTechniczne, Warszawa (2010)

18. A. Kowalczyk, J. Kutryn, T. Piecuch, Annual Set the Environment, 12, (2010)

19. A. Kowalczyk, T. Piecuch, Inżynieria ekologiczna, 25, (2011)

20. A. Kowalczyk, T. Piecuch, L. Andriyevska, Annual Set the Environment, 15, (2013) 